\title{
Consumption and release of dissolved organic carbon by marine bacteria in a pulsed-substrate environment: from experiments to modelling
}

\author{
M. Eichinger ${ }^{1,3, *}$, S. A. L. M. Kooijman ${ }^{2}$, R. Sempéré ${ }^{1}$, D. Lefèvre ${ }^{1}$, G. Grégori $^{1}$, \\ B. Charrière ${ }^{1}$, J. C. Poggiale ${ }^{1}$ \\ ${ }^{1}$ Université de la Méditerranée, Laboratoire de Microbiologie Géochimie et Ecologie Marines (LMGEM) CNRS/INSU, \\ UMR 6117, Centre d'Océanologie de Marseille, Campus de Luminy, Case 901, 13288 Marseille Cedex 9, France \\ ${ }^{2}$ Vrije Universiteit, Faculty of Earth and Life Science, Department of Theoretical Biology, de Boelelaan 1087, \\ 1081 HV Amsterdam, The Netherlands
}

${ }^{3}$ Present address: IFREMER Centre de Brest, Département de Biogéochimie et Ecotoxicologie, BP 70, 29280 Plouzané, France

\begin{abstract}
To investigate the effects of episodic occurrence of dissolved organic carbon (DOC) in the natural environment, bacterial degradation of labile DOC was studied under laboratory- controlled conditions followed by modelling. A single labile DOC compound was periodically added to the experimental culture and its degradation by a monospecific marine bacterial strain was followed. The measured variables were DOC and bacterial biomass determined from the particulate organic carbon values. Experimental dynamics showed a repetition of 2 successive patterns after each DOC pulse: (1) substrate consumption and bacterial growth in the first few hours after substrate addition, followed by (2) bacterial reduction (organic carbon-related) and associated non-labile DOC release within the next few hours. Based on these experimental results, the Dynamic Energy Budget theory was applied for the first time to such conditions to develop a mechanistic model that comprised 7 parameters and 4 state variables in which bacterial biomass was fractionated into reserve and structure compartments. The model was constructed by accounting for a constant specific maintenance rate and comprised 2 different cell maintenance fluxes, one fuelled from cell reserves when substrate was abundant and one from reserves and cell structures when starvation occurred. This new model of bacterial degradation adequately matched experimental measurements and accurately reproduced the accumulation of non-labile DOC in the culture during the experiment. This model can easily be implemented in an aquatic biogeochemical model and could provide better understanding of the role of bacteria in carbon cycling in fluctuating environments.
\end{abstract}

KEY WORDS: Bacterial dynamics - DOC degradation - DOC release - Mechanistic model . DEB theory

\section{INTRODUCTION}

Depending on bacterial reactivity, dissolved organic carbon (DOC) can be fractionated into several components, including labile DOC (L-DOC) with turnover rates from hours to days, semi-labile DOC (SL-DOC) with turnover rates of months to years, and refractory DOC (R-DOC) with turnover rates of millennia and which accumulates in the ocean (Carlson \& Ducklow 1995, Hansell et al. 1995). DOC in the water column, especially the labile component, is almost exclusively consumed by bacteria (Azam 1998), and is thus either transformed into $\mathrm{CO}_{2}$ or transferred to higher trophic levels. Despite their important ecological role, bacteria are rarely or poorly represented in global models (Arhonditsis \& Brett 2004), and various biogeochemical formulations and parameters, including L-DOC dynamics and bacterial growth efficiency, are often obtained from a basic description of the natural environment. For instance, models have described bacter- 
ial assimilation of DOC in batch cultures in which excess DOC or particulate organic carbon (POC), added at the beginning of the experiments, were consumed by bacteria over time and without any perturbation (Zweifel et al. 1993, Carlson \& Ducklow 1996, Sempéré et al. 2000, Carlson et al. 2002, Sempéré et al. 2003, Cherrier \& Bauer 2004, Eichinger et al. 2006). However, the ecosystem is much more dynamic than batch cultures. Substrate is not continuously available in the natural environment (Hanegraaf et al. 2000) and bacterial carbon demand is usually fuelled by episodic inputs of dissolved organic matter (DOM). For instance, fluctuation of DOC availability varies spatially, from microzones containing elevated substrate concentrations at a scale of millimetres (Williams 2000) to regional scales, such as the nearshore zones influenced by upwelling events (McManus \& Peterson 1988). Similarly, because of DOC release by phytoplankton, DOC may fluctuate daily in relation to phytoplankton responses to light (Coffin et al. 1993), seasonally due to its release during a bloom (Miki \& Yamamura 2005, Grossart \& Simon 2007), or more unpredictably and locally when phytoplankton is enhanced by the uplift of the nutricline into the euphotic zone by mesoscale eddies (Mouriño-Carballido \& Neuer 2008).

Similarly, most biogeochemical models are related to the empirical Monod model (Monod 1942), using Michaelis-Menten kinetics (Michaelis \& Menten 1913), to describe bacterial growth on L-DOC (BarettaBekker et al. 1995, Blackburn et al. 1996, Anderson \& Williams 1998, 1999, Lancelot et al. 2002, Raick et al. 2005). However, some studies have demonstrated that the Monod model is too simplistic for complex environments; specifically, the inclusion of a reserve compartment and a maintenance term, such as those described in the Dynamic Energy Budget (DEB) theory (Kooijman 2000), would be necessary to fit single-species growth curves from chemostats and batch systems (Martinussen \& Thingstad 1987). The reserve compartment and maintenance may play crucial roles in bacterial dynamics; the former acts as a buffer, allowing bacteria to survive during starvation periods, and the latter represents the energetic cost for a cell to survive. DEB theory accounts for these 2 processes and has been widely tested against experimental data, including microbial dynamics, in trophic chains in a chemostat (Kooi \& Kooijman 1994), biodegradation of multiple substrates (Brandt et al. 2003), adaptation to changing substrate availability (Brandt et al. 2004), and application of mass energy conservation laws (Kooijman et al. 1999). However, models constructed from DEB theory have never been used in biogeochemical models due to their complexity and to the number of state variables and parameters.
The present study specifically focusses on the processes that must be included in a bacterial growth model in order to later implement it in biogeochemical models. This model must be able to reproduce bacterial dynamics in a variable environment, as characterised here by fluctuations in DOC supply. To this end, we conducted experiments on bacterial DOC degradation after pulsed addition of a DOC compound to a bacterial culture. This simplified system reproduced the dynamics in the natural, variable environment and allowed the examination of bacterial processes that could not be observed in situ. We then used the observed experimental results to construct and calibrate a mechanistic model based on DEB theory (Kooijman 2000). We compared the model results with our experimental data and tested the effects of substrate concentration and period on simulated dynamics. Finally, our results are discussed in relation to modelling of the carbon cycle.

\section{MATERIALS AND METHODS}

Experiments. To mimic the episodic occurrence of L-DOC in the natural environment, pyruvate $(1.6 \mathrm{mM}$ C) was added every $48 \mathrm{~h}$ over $10 \mathrm{~d}$ to an artificial seawater culture containing a single bacterial strain, Alteromonas infernus, with a cell density of $6 \times 10^{6}$ cells $\mathrm{ml}^{-1}$. The solution was incubated in the dark at $25 \pm$ $1^{\circ} \mathrm{C}$ and continuously gently swirled. The $A$. infernus strain originated from a hydrothermal vent, is motile, strictly aerobic, non-fermentative, non-luminescent, non-pigmented, and encapsulated. It is a Gram-negative rod, 0.6 to $0.8 \mu \mathrm{m}$ wide by 1.4 to $2 \mu \mathrm{m}$ long with a single polar flagellum (Raguénès et al. 1997). We selected pyruvate as the carbon substrate because of its labile character and because it is the first substrate in the Krebs cycle. The $48 \mathrm{~h}$ pulse period was chosen so that bacteria were starved between 2 successive pulses, allowing study of cell maintenance and relevance of a reserve compartment, both of which are key concepts in DEB theory. For the purpose of modelling, substrate concentration was higher than in the natural environment, which allowed for a robust substrate decrease and bacterial growth measurement. Except for the energy and carbon substrate, all other nutrients were added in excess. $\mathrm{KH}_{2} \mathrm{PO}_{4}$ and $\mathrm{NH}_{4} \mathrm{Cl}$ were provided only at the beginning of the experiment at concentrations of 0.2 and $6.7 \mathrm{mM}$, respectively. Bottles were filled to $75 \%$ of the bottle volume to ensure welloxygenated conditions. Our simplified system, comprised of only one bacterial strain and one DOC substrate, allowed a direct relationship between the observed bacterial growth and DOC consumption. This was highly advantageous for identifying and 
quantifying implemented processes for model construction and calibration, which is not possible when working from natural samples.

Sampling was done 3 or 4 times per day, with special attention to sampling each time just before and just after substrate addition. DOC, including pyruvate (LDOC) and all other DOC forms that were produced during the experiment, and $\mathrm{POC}$, corresponding to the bacterial biomass in carbon, were sampled. DOC and POC were separated on pre-combusted GF/F filters (0.7 $\mu \mathrm{m}$ nominal porosity). DOC concentration was measured by HTCO (high temperature catalytic oxydation) with a Schimadzu TOC 5000 (Sempéré et al. 2003) and POC concentration by combustion with a Leco SC-144 carbon analyser (Sempéré et al. 2000). Samples for DOC analysis were also checked for bacterial density by flow cytometry (Robinson \& Grégori 2007) to determine bacterial passage through the filters (data not shown); only $2 \pm 3 \%$ of bacteria passed through the filter $(27$ samples checked out of 33 samples). In more than $90 \%$ of the samples, $<5 \%$ of bacteria passed through the filters, with a maximum of $13 \%$. Because these percentages were negligible, we did not correct data for bacteria in the DOC samples. The reproducibility of the results was determined by conducting triplicate experiments independently ( $\mathrm{M}$. Eichinger et al. unpubl, data), justifying the use of deterministic methods to describe DOC consumption and bacterial growth.

Total bacterial density (TBD) was also measured during the experiment at the same time as DOC and POC. TBD was estimated by counts under an epifluorescent microscope (Olympus BX61) after diamidino-4', 6phenylindol-2 dichlorhydrate (DAPI) $\left(2.5 \mu \mathrm{g} \mathrm{cm}^{-3}\right.$ final concentration) staining (Van Wambeke et al. 2004); however, we present only those experimental results used to develop and calibrate the carbon-based model, i.e. DOC and POC. Nevertheless, some of the TBD data, with flow cytometry counts in DOC samples, were used to support some hypotheses of the model.

Modelling. The model was constructed from DEB theory, which assumes that bacterial biomass consists of reserve plus structure components (Kooijman 2000) and which we measured at the population level (POC concentration). In the context of DEB theory, the reserve compartment may contain many compounds and is a buffer that explains continued growth after substrate depletion and allows variable stoechiometry when multiple reserve systems are considered (Kooijman 2000). Carbon storage by bacteria has been demonstrated in previous studies. For instance, accumulation of storage lipids, which serve as endogenous carbon and energy sources during starvation periods, has been assumed to be a potential adaptation mechanism for coping with nutrient limitation (Kalscheuer et al. 2007). In carbon-limited systems, bacteria are able to store carbon as poly- $\beta$-hydroxybutyrate (PHB), which is a survival mechanism to dispose of the excess substrate taken up (Baxter \& Sieburth 1984).

Based on our experimental results (see section 'Results: Experiments'), the model consisted of 2 sets of differential equations or sub-models, each corresponding to a phase of the dynamics (i.e. growth phase and reduction phase). We used the notation $j \cdot *_{1} \cdot 2$ (or $j *_{1}^{2}$ ) for specific fluxes and $\dot{J}_{*_{1 \cdot 2}}=j_{\cdot_{1} *_{2}} M_{V}$ for absolute fluxes, i.e. fluxes of state variable $\cdot{ }_{1}$ associated with process $\cdot_{2}$ (processes were assimilation, maintenance, and growth; Kooijman 2000 and Table 1). The notation $y \cdot 1 \cdot 2$ was used for the yield coefficients representing the efficiency of transformation of state variable ${ }_{2}$ to state variable $\cdot_{1}$. Conceptual functioning of the model is shown in Fig. 1, and all notations, state variables, and parameters are listed in Table 1 . The model comprised 4 state variables:

$L$, L-DOC concentration (mM C), which represented pyruvate/substrate concentration

$R, \mathrm{R}$-DOC concentration (mM C), which represented the un-utilised DOC that accumulated during the experiment

$M_{E}$, reserve concentration (mM C)

$M_{V}$, structure concentration (mM C)

To compare model outputs with observations, we assumed that (1) the sum of both DOC pools corresponded to the DOC concentration measured and (2) the sum of both bacterial compartments corresponded to the total bacterial biomass or POC concentration measured:

$$
\begin{gathered}
\mathrm{DOC}=L+R \\
\mathrm{POC}=M_{V}+M_{E}
\end{gathered}
$$

The growth model corresponded to the typical bacterial DEB model and was used to reproduce experimental dynamics after substrate addition. In that case, the model simulated substrate consumption using a Michaelis-Menten kinetic, which was proportional to substrate and structure concentrations (Appendix 1, Eq. A7). Substrate was assimilated into the reserve compartment with efficiency $y_{M_{E} L^{\prime}}$ a part of reserve being spent for maintenance requirements $\dot{J}_{M_{E}}^{M}$ and another part being used for growth of the structural volume $\dot{J}_{M_{E} G}$. The resulting reserve dynamic equation was as follows:

$$
\frac{\mathrm{d} M_{E}}{\mathrm{~d} t}=y_{M_{E} L} \frac{\mathrm{d} L}{\mathrm{~d} t}-\dot{J}_{M_{E}}^{M}-\dot{J}_{M_{E} G}
$$

Growth of the structural compartment originated directly from reserve (Fig. 1a) (Appendix 1, Eqs. A8 \& A9):

$$
\frac{\mathrm{d} M_{V}}{\mathrm{~d} t}=y_{M_{V} M_{E}} \dot{J}_{M_{E} G}
$$


Table 1. Description and units of all notations, state variables and parameters used in specification of the Dynamic Energy Budget (DEB) model of bacterial carbon cycling

\begin{tabular}{|c|c|c|c|}
\hline Symbol & Equivalent & Unit & Description \\
\hline \multicolumn{4}{|c|}{ Notations } \\
\hline$j \cdot 1 \cdot 2$ & $\frac{\dot{J}_{\cdot 1 \cdot 2}}{M_{V}}$ & $\mathrm{~h}^{-1}$ & Specific flux of state variable $\cdot{ }_{1}$ associated with process $\cdot 2$ \\
\hline$j \cdot *_{1}^{2}$ & $\frac{\dot{J}_{1}^{*} 2}{M_{V}}$ & $\mathrm{~h}^{-1}$ & $\begin{array}{l}\text { Specific flux of state variable } \cdot{ }_{1}\left(1=M_{E} \text { or } M_{V}\right) \text { associated to } \\
\text { maintenance }(2=M)\end{array}$ \\
\hline$y \cdot 1 \cdot 2$ & $\frac{1}{y \cdot 2 \cdot 1}$ & - & Yield coefficient of state variable ${ }_{2}$ on state variable $\cdot 1$ \\
\hline \multicolumn{4}{|c|}{ Processes } \\
\hline A & & & Assimilation \\
\hline M & & & Maintenance \\
\hline$G$ & & & Growth \\
\hline \multicolumn{4}{|c|}{ State variables } \\
\hline$L$ & & $\mathrm{mM} \mathrm{C}$ & Substrate (L-DOC) concentration \\
\hline$M_{E}$ & & $\mathrm{mM} \mathrm{C}$ & Reserve concentration \\
\hline$M_{V}$ & & $\mathrm{mM} \mathrm{C}$ & Structure concentration \\
\hline$m_{E}$ & $\frac{M_{E}}{M_{V}}$ & - & Reserve density \\
\hline$R$ & & $\mathrm{mM} \mathrm{C}$ & R-DOC (non-labile DOC) concentration \\
\hline \multicolumn{4}{|c|}{ Parameters } \\
\hline $\begin{array}{l}j_{L A m} \\
K\end{array}$ & & $\begin{array}{c}\mathrm{h}^{-1} \\
\mathrm{mMC}\end{array}$ & $\begin{array}{l}\text { Maximum specific substrate utilisation rate } \\
\text { Half-saturation constant }\end{array}$ \\
\hline$\alpha$ & $\frac{j_{L A m}}{K}$ & $\mathrm{mM} \mathrm{C}^{-1} \mathrm{~h}^{-1}$ & $\begin{array}{l}\text { Ratio between the maximum specific utilisation rate and the half- } \\
\text { saturation constant }\end{array}$ \\
\hline$y_{M_{E} L}$ & & - & Yield coefficient from L-DOC to reserve \\
\hline$y_{M_{E} M_{V}}$ & & - & Yield coefficient from structure to reserve \\
\hline$k_{E}$ & & $\mathrm{~h}^{-1}$ & Reserve turnover rate \\
\hline$j_{M_{E} M}$ & & $\mathrm{~h}^{-1}$ & Maintenance flux from reserve \\
\hline$j_{M_{V} M}$ & & $\mathrm{~h}^{-1}$ & Maintenance flux from structure \\
\hline$Y_{R M_{V}}$ & & - & Yield coefficient from structure to R-DOC \\
\hline
\end{tabular}

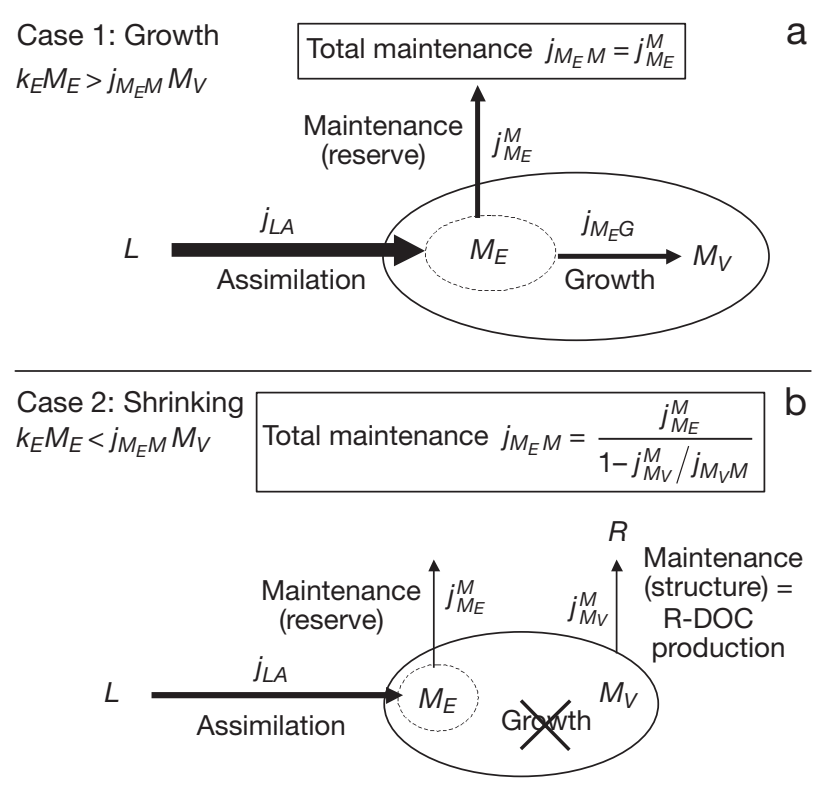

a We developed the reduction sub-model to reproduce the decrease of the specific carbon content (Fig. 3b) and the accumulation of DOC (Fig. 2) originating from bacterial release (see 'Results: Experiments'). We used a switch formulation to specify the use of one and/or another sub-model (Tolla et al. 2007). This switch was a function of reserve and structure concentration

Fig. 1. Dynamic Energy Budget (DEB) model including (a) growth (Case 1) and (b) reduction (organic carbon-related, Case 2). State variables involved in the theoretical cell functioning are as follows: $L$ (substrate or labile dissolved organic carbon, L-DOC), $M_{E}$ (reserve mass), $M_{V}$ (structural mass) and $R$ (refractory dissolved organic carbon (R-DOC)). The various processes involved are assimilation (A), maintenance (M) and growth (G). $j_{1}^{*}$ and $j_{*_{1} \cdot 2}$ represent the specific fluxes of state variable $\cdot{ }_{1}$ associated with process $\cdot_{2}$. The notation $j *_{1}^{2}$ is here specifically used when dealing with maintenance. The arrow thicknesses are proportional to the amount of available substrate, and once in the cell to the assimilation flux 


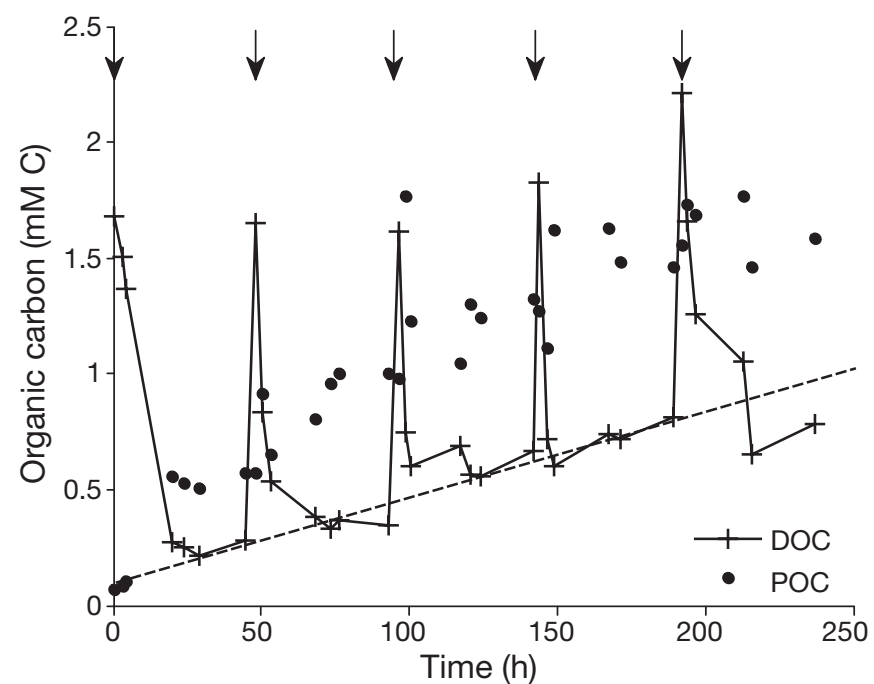

Fig. 2. Concentrations of dissolved and particulate organic carbon (DOC and POC, in $\mathrm{mM} \mathrm{C}$ ) measured in an experiment with a substrate pulse at $48 \mathrm{~h}$ intervals, as represented by the arrows. DOC represents the substrate (pyruvate) plus all other DOC forms produced during the experiment, and POC represents the bacterial biomass. DOC dynamics are visualized by lines connecting the data points. Dashed line: DOC accumulation throughout the experiment
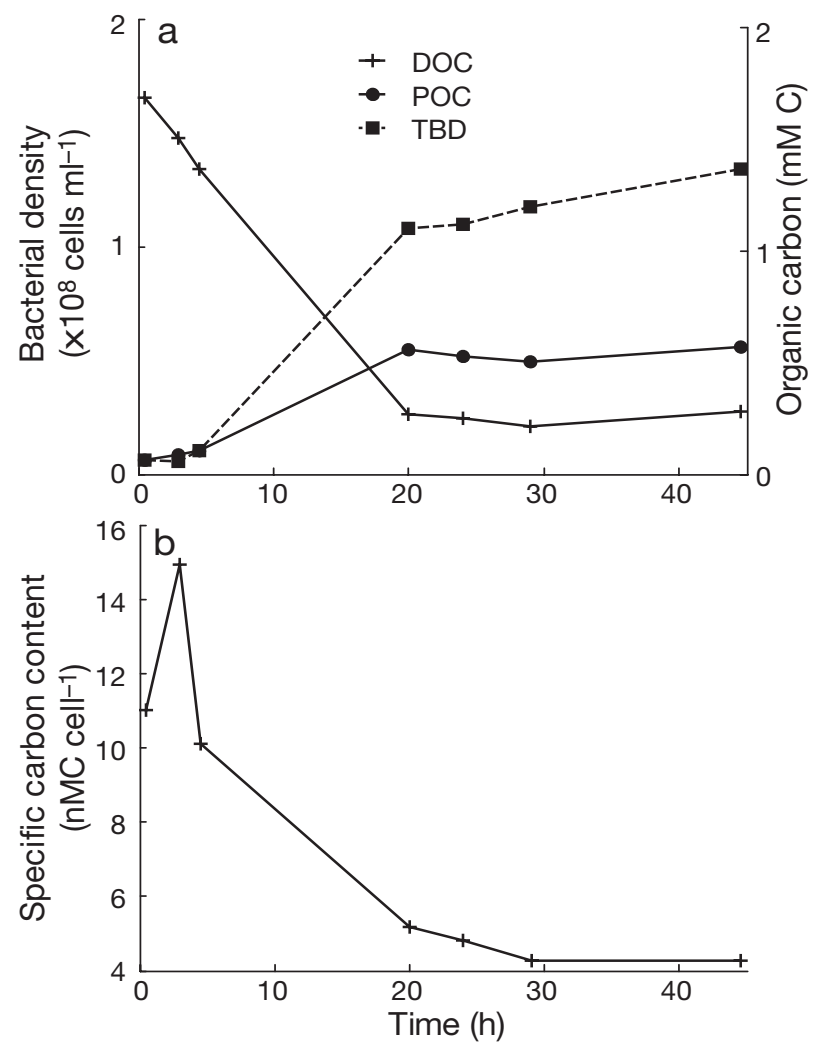

Fig. 3. Dynamics following the first addition of DOC at $0 \mathrm{~h}$ of (a) dissolved and particulate organic carbon (DOC and POC, in $\mathrm{mM} \mathrm{C}$ ) and total bacterial density (TBD, in cells $\mathrm{ml}^{-1}$ ), and (b) specific carbon content of bacteria (nMC cell ${ }^{-1}$ ), calculated as follows: specific carbon content $=$ POC $/ \mathrm{TBD}$ values (see Appendix 1 for a detailed explanation of the switch formulation). When the reserve density

$$
m_{E}=\frac{M_{E}}{M_{V}}
$$

was high enough, we used the growth sub-model described above; otherwise, we used the reduction sub-model. This sub-model was constructed on the basis of the maintenance requirement, which must be constant according to a given structure concentration (Appendix 1). Thus, maintenance was paid from mobilised reserve in the growth sub-model $\left(\dot{J}_{M_{E}}^{M}\right)$ (Fig. 1a), and structure itself was used to pay the remainder of the maintenance costs $\left(\dot{J}_{M_{V}}^{M}\right)$ in the reduction sub-model, implying R-DOC production (Fig. 1b). The equation for substrate uptake was the same in the reduction and growth sub-models. All reserve was used for maintenance:

$$
\frac{\mathrm{d} M_{E}}{\mathrm{~d} t}=y_{M_{E} L} \frac{\mathrm{d} L}{\mathrm{~d} t}-\dot{J}_{M_{E}}^{M}
$$

No more carbon was transferred to the structural compartment $\left(\dot{J}_{M_{E} G}=0\right)$, and structure itself was used to fulfil maintenance requirements (Fig. 1b):

$$
\frac{\mathrm{d} M_{V}}{\mathrm{~d} t}=-\dot{J}_{M_{V}}^{M}
$$

A proportion $y_{R M_{V}}$ of this structural carbon used for maintenance was released as R-DOC in ambient water (Appendix 1, Eqs. A8 \& A9):

$$
\frac{\mathrm{d} R}{\mathrm{~d} t}=y_{R M_{V}} \frac{\mathrm{d} M_{V}}{\mathrm{~d} t}
$$

Combining Eqs. (2) to (6), we obtained the following switch DEB model (see Appendix 1 for a detailed explanation of model formulation):

$\frac{\mathrm{d} L}{\mathrm{~d} t}=-j_{L A m} \frac{L}{K+L} M_{V}$

if $k_{E} M_{E}>j_{M_{E} M} M_{V} \quad$ if $k_{E} M_{E}<j_{M_{E} M} M_{V}$

$\left\{\begin{array}{l}\frac{\mathrm{d} M_{E}}{\mathrm{~d} t}=y_{M_{E} L} \frac{\mathrm{d} L}{\mathrm{~d} t}-\dot{J}_{M_{E}}^{M_{E}}-\dot{J}_{M_{E} G} \\ \frac{\mathrm{d} M_{V}}{\mathrm{~d} t}=y_{M_{V} M_{E}} \dot{J}_{M_{E} G} \\ \frac{\mathrm{d} R}{\mathrm{~d} t}=0\end{array}\left\{\begin{array}{l}\frac{\mathrm{d} M_{E}}{\mathrm{~d} t}=y_{M_{E} L} \frac{\mathrm{d} L}{\mathrm{~d} t}-\dot{J}_{M_{E}}^{M} \\ \frac{\mathrm{d} M_{V}}{\mathrm{~d} t}=-\dot{J}_{M_{V}}^{M} \\ \frac{\mathrm{d} R}{\mathrm{~d} t}=y_{R M_{V}} \dot{J}_{M_{V}}^{M}\end{array}\right.\right.$

To test the model and the relevance of the included processes, we estimated parameter values that corresponded to the experimental results (Table 2). Calibration was based on minimisation of the sum of squared deviations of model predictions to data points using the Nelder Mead's simplex method (Lagaria et al. 1998). All parameters were estimated simultaneously using the whole data set, considering $L+R=$ DOC and $M_{V}+$ $M_{E}=$ POC. Results from model calibration allowed the utilisation of a linear equation for substrate uptake:

$$
\frac{\mathrm{d} L}{\mathrm{~d} t}=-\alpha L M_{V}, \text { where } \alpha=\frac{j_{L A m}}{K}
$$


Table 2. Parameter and initial condition values for the Dynamic Energy Budget (DEB) model (Appendix 1, Eq. A9). Parameters have been estimated from the minimisation of the sum of squared deviations between model outputs and experimental data (Fig. 2). State variables and parameters are given in Table 1

\begin{tabular}{|lc|}
\hline & Values \\
\hline Parameters & \\
$\alpha$ & 0.484 \\
$k_{E}$ & 0.603 \\
$Y_{M_{E} L}$ & 0.500 \\
$Y_{M_{E} M_{V}}$ & 1.492 \\
$j_{M_{E} M}$ & 0.000 \\
$j_{M_{V} M}$ & 0.008 \\
$Y_{R M_{V}}$ & 1.000 \\
Initial conditions & \\
$L(0)$ & 1.369 \\
$M_{E}(0)$ & 0.000 \\
$M_{V}(0)$ & 0.098 \\
$R(0)$ & 0.314 \\
\hline
\end{tabular}

(Appendix 1). This reduced the model to 7 parameters and 4 state variables.

\section{RESULTS}

\section{Experiments}

DOC and POC dynamics repeated the same pattern during each pulse period (Fig. 2). DOC concentration decreased during the first pulse period 0 to $45 \mathrm{~h}$ after substrate addition, indicating substrate consumption (Fig. 3a). POC concentration and TBD increased a few hours after the start of substrate consumption (Fig. 3a), indicating bacterial growth and increasing bacterial carbon content (Fig. 3b). About $20 \mathrm{~h}$ after the first substrate addition, DOC concentration did not decrease further and POC concentration stabilized or decreased (Fig. 3a). This occurred faster for subsequent pulse periods because TBD increased throughout the experiment. Simultaneously, TBD increased (Fig. 3a), which indicated decreasing specific carbon content (Fig. 3b). In the present study, we called this process bacterial reduction. Over the whole experiment, the growth period averaged a $1.3 \mathrm{mM}$ DOC decrease after each pulse and a smaller POC increase (Fig. 2). During the reduction (C-related) periods, DOC increased slightly a few hours after each substrate pulse, ranging from a negligible amount following the first pulse to $0.2 \mathrm{mM} \mathrm{C}$ after the last pulse (Fig. 2). Overall, the unconsumed DOC concentration increased from $0.2 \mathrm{mM} \mathrm{C}$ after the first substrate pulse to $0.8 \mathrm{mM} \mathrm{C}$ at the end of the experiment, as shown by the dashed line in Fig. 2. This DOC accumulation paralleled the decrease in specific carbon content (Fig. 3). Because of our experimental design, the only potential source for this increase in DOC concentration was bacterial release due to bacterial reduction (decrease in carbon content per cell). Flow cytometry analyses showed that dead material was scarce in DOC samples (data not shown), which supports the idea that the accumulating DOC material did not consist of dead bacterial cells due to, for example, viral infection. Thus, we conclude that the unconsumed and accumulated DOC was produced by starved bacteria and released during the reduction process. This assumption is supported by previous investigations demonstrating DOC release by bacteria in laboratory experiments (Stoderegger \& Herndl 1998, Ogawa et al. 2001, Gruber et al. 2006). Finally, the nature of the DOC pool has very likely changed over the course of the experiment, since freshly added pyruvate should have been consumed rapidly. Consequently, we refer to the substrate as L-DOC and to the produced and accumulated DOC as R-DOC.

\section{Modelling}

Mechanistic description of bacterial growth

Experimental results allowed construction of a mechanistic model for bacterial degradation described by the system of differential equations (Eq. 7), with additional details in Eq. (A9) (Appendix 1). Equations on the left correspond to a typical DEB growth model for bacteria (Fig. 1a) and the system on the right describes model behaviour during bacterial carbon reduction, which caused DOC release (Fig. 1b). The model comprised 4 carbon state variables, whereas we realised 2 carbon measurements in the experimental batch. DOC was split into 2 state variables, L-DOC and R-DOC (RDOC corresponding here to un-utilised or accumulated DOC, as detailed in 'Results: Experiments'), and POC was in reserve plus structure compartments. All parameters were estimated simultaneously and gave suitable simulations according to the present data set (Fig. 4c,f). We may thus assume that (1) the separation of DOC and POC into 2 separate pools and (2) estimated values of parameters accurately represented activities of the studied bacterial strain (Tables 1 \& 2). Indeed, the model is able to simulate the rapid substrate consumption after its addition (Fig. 4a), which was followed by increased reserve concentration (Fig. 4d) and then, with a small time lag, structure concentration (Fig. 4e). The model also showed that reserve and structure concentrations decreased (Fig. 4d-e) when substrate was no longer available a few hours after its addition (Fig. 4a). Simultaneously with the decrease of the bacterial carbon content (Fig. 4f), the model simulated R-DOC release in the ambient medium (Fig. 4b) 

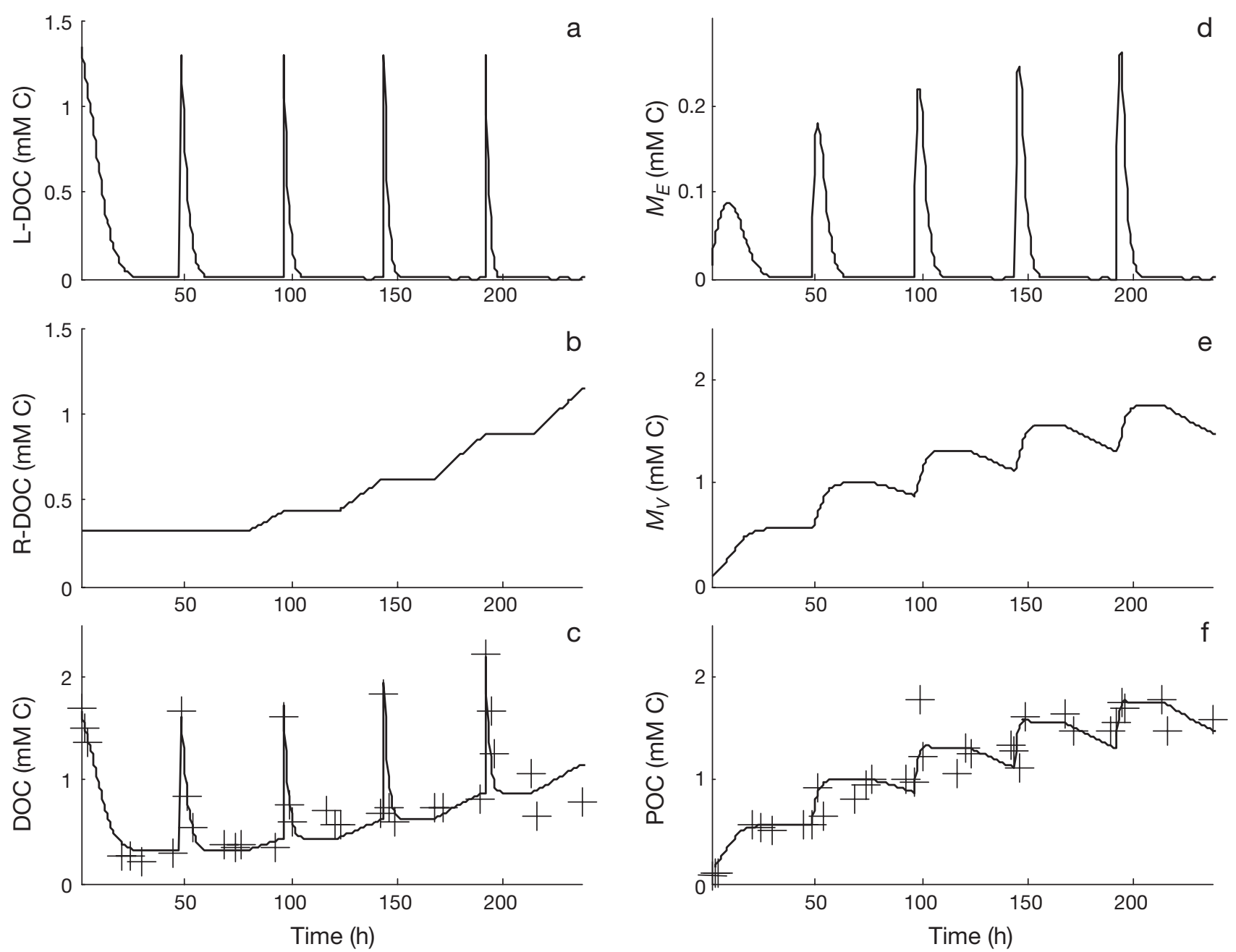

Fig. 4. Dynamics of $(\mathrm{a}-\mathrm{c})$ dissolved organic carbon (DOC, in $\mathrm{mM} \mathrm{C}$ ) and (d-f) bacterial state variables (mM C) for the Dynamic Energy Budget (DEB) model. crosses: experimental data; lines: outputs of the model with the fitted parameter set for the DEB model (Table 2); DOC $=L+R$ and POC $=M_{V}+M_{E}$. L: labile DOC or L-DOC, $R$ : refractory DOC or R-DOC; $M_{V}$ : structure concentration; $M_{E}$ : reserve concentration

and thus the increase of the total DOC concentration (Fig. 4c). Model simulations exhibited no production of R-DOC during the first pulse period. Consequently, these kinds of dynamics, highlighting DOC release, could not be observed from typical batch experiments with a unique substrate addition.

Our model was constructed on the principle of maintenance requirement. It is important to note that the total specific maintenance cost was constant and equaled:

$$
j_{M_{E} M}=\frac{j_{M_{E}}^{M}}{1-j_{M_{V}}^{M} / j_{M_{V} M}}
$$

(Fig. 1 and Appendix 1). The advantage of our mechanistic maintenance formulation was that it allowed switching between both sub-models as a function of the physiological state of the bacteria. Consequently, during growth conditions, $j_{M_{V}}^{M}$ is null and maintenance was fully realised from the reserve compartment $\left(j_{M_{E} M}=j_{M_{E}}^{M}\right) ;$ however, during starvation, structural volume was also used to complete maintenance requirements. In that case, the amount of energy used from reserve and from structure was a function of the specific growth rate (Appendix 1, Eq. A4).

Effects of pulse period and concentration on bacterial and DOC dynamics for in situ conditions

To test the relevance of such a model for in situ conditions, several simulations with various L-DOC pulse periods and concentrations were performed. The initial R-DOC concentration was set to $40 \mu \mathrm{M} \mathrm{C}$, which corresponds approximately to DOC concentrations 
a
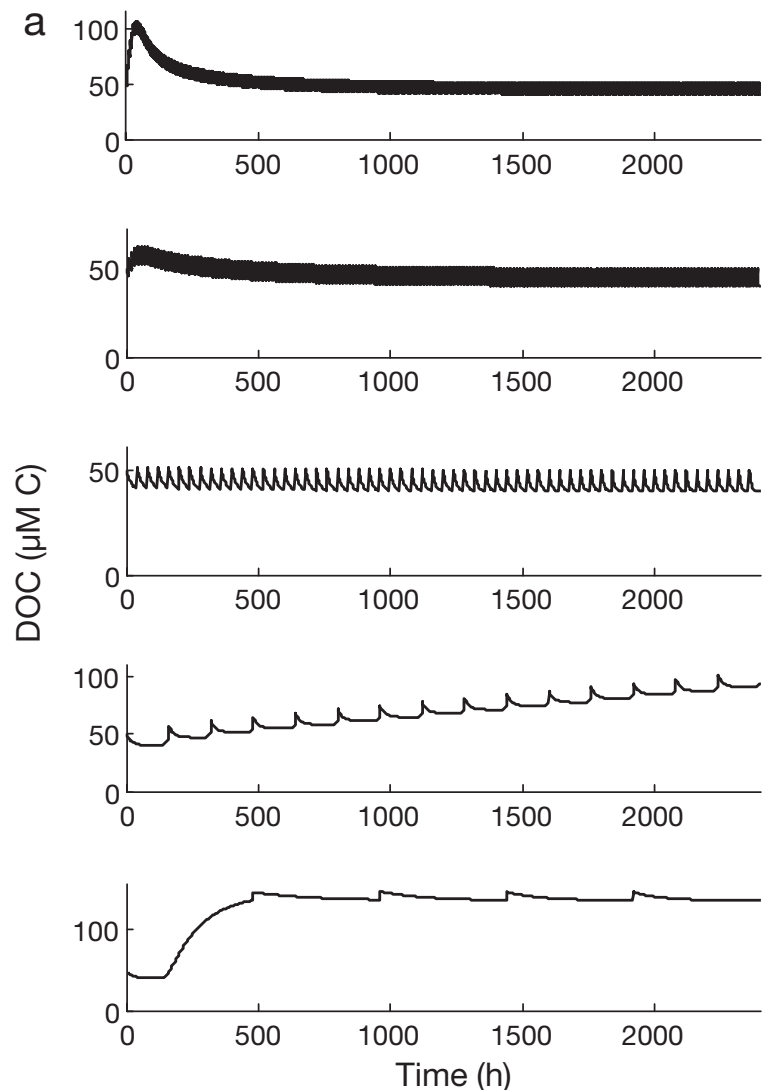

$T=2.5 \mathrm{~h}$

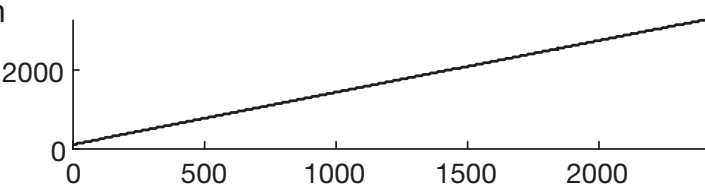

$T=10 \mathrm{~h}$

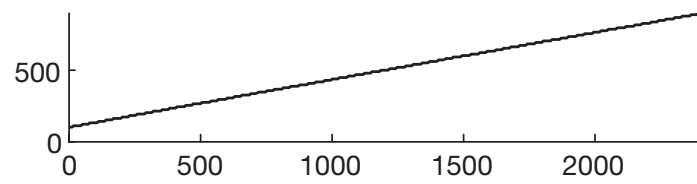

$T=40 \mathrm{~h}$

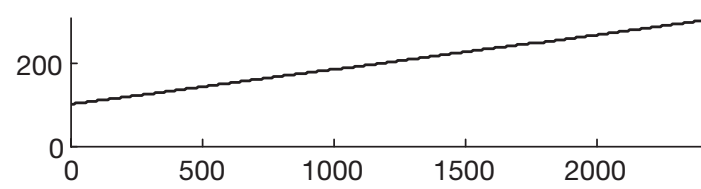

$T=160 \mathrm{~h}$

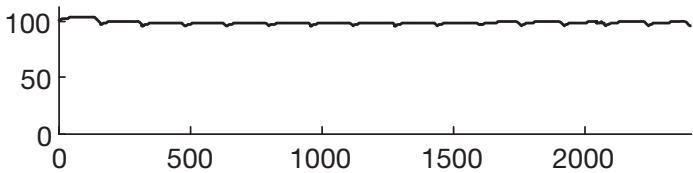

$T=480 \mathrm{~h}$

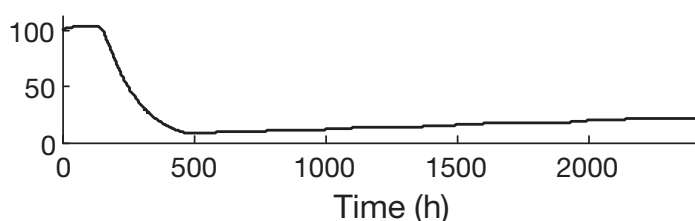

Fig. 5. Simulations of dissolved organic carbon (DOC) ( $\mu \mathrm{M}$ C) and bacterial biomass ( $\mu \mathrm{M}$ C) dynamics for (a) different pulse periods and (b, on opposite page) different labile dissolved organic carbon (L-DOC) pulse concentrations. Simulations were realised with initial refractory DOC (R-DOC) concentrations of $40 \mu \mathrm{M} \mathrm{C}$ and the same initial bacterial biomass as in the batch experiment $\left(M_{E}=0 \mu \mathrm{M} \mathrm{C}\right.$ and $M_{V}=98 \mu \mathrm{M}$ C, Table 2). (a) Initial simulations were realised with a L-DOC pulse concentration (I) of $10 \mu \mathrm{M} \mathrm{C}$ and pulse periods ( $T$ ) from 2.5 to $480 \mathrm{~h}$. (b) $T$ was fixed to $160 \mathrm{~h}$, but $I$ differed between 5 and $160 \mu \mathrm{M} \mathrm{C}$. Model outputs are directly represented as the sum of L-DOC $(L)$ and R-DOC $(R)$ (DOC $=L+R)$, and of the sum of the reserve $\left(M_{V}\right)$ and structure

$\left(M_{E}\right)$ components of bacterial biomass (bacterial biomass $=M_{V}+M_{E}$ )

found in the deep ocean (Hansell \& Carlson 1998). The same initial values were used for reserve and structure concentrations because initial bacterial density in the experiment was similar to natural conditions. Consequently, only either the pulse L-DOC concentration or the pulse period were changed. We tested L-DOC concentrations (I) from 5 to $160 \mu \mathrm{M} \mathrm{C}$, corresponding to realistic L-DOC concentrations in surface waters, and pulse periods $(T)$ from 2.5 to $480 \mathrm{~h}$, corresponding to different oceanic systems. Each simulation was realised on $2400 \mathrm{~h}$ (100 d).

When periodic input of a small concentration of L-DOC was considered (Fig. 5a, $I=10 \mu \mathrm{M} \mathrm{C}$ ), the model showed different dynamics according to the pulse period. For short pulse periods $(T=2.5,10$, and $40 \mathrm{~h}$ ), the system was equivalent to a system with continuous input of substrate. Indeed, bacterial biomass continuously increased during the simulation and DOC concentration rapidly stabilised. For the shortest periods ( $T=2.5$ and 10 h, Fig. 5a), L-DOC accumulated at the beginning of the simulation. For the first 3 pulse periods tested $(T=2.5,10$, and $40 \mathrm{~h})$, dynamics did not exhibit R-DOC release and bacterial biomass decrease. When the pulse period was increased, simulations showed R-DOC production linked to decreased bacterial biomass. For $T=160 \mathrm{~h}$, a continuous increase of DOC was observed, which was due to R-DOC release as soon as all L-DOC was consumed. Bacterial biomass varied only slightly, but did not increase over the time course of the simulation, demonstrating that this L-DOC concentration and pulse period were just sufficient to maintain the bacterial population. For $T=$ $480 \mathrm{~h}(20 \mathrm{~d})$, considerable production of non-labile DOC after the first pulse was associated with a pronounced decrease of bacterial biomass. After the second pulse, the system was at steady-state with a continuous and slight increase of bacterial biomass and no production of R-DOC. Substrate regime and concentration were just sufficient to maintain the current population after the second pulse. 


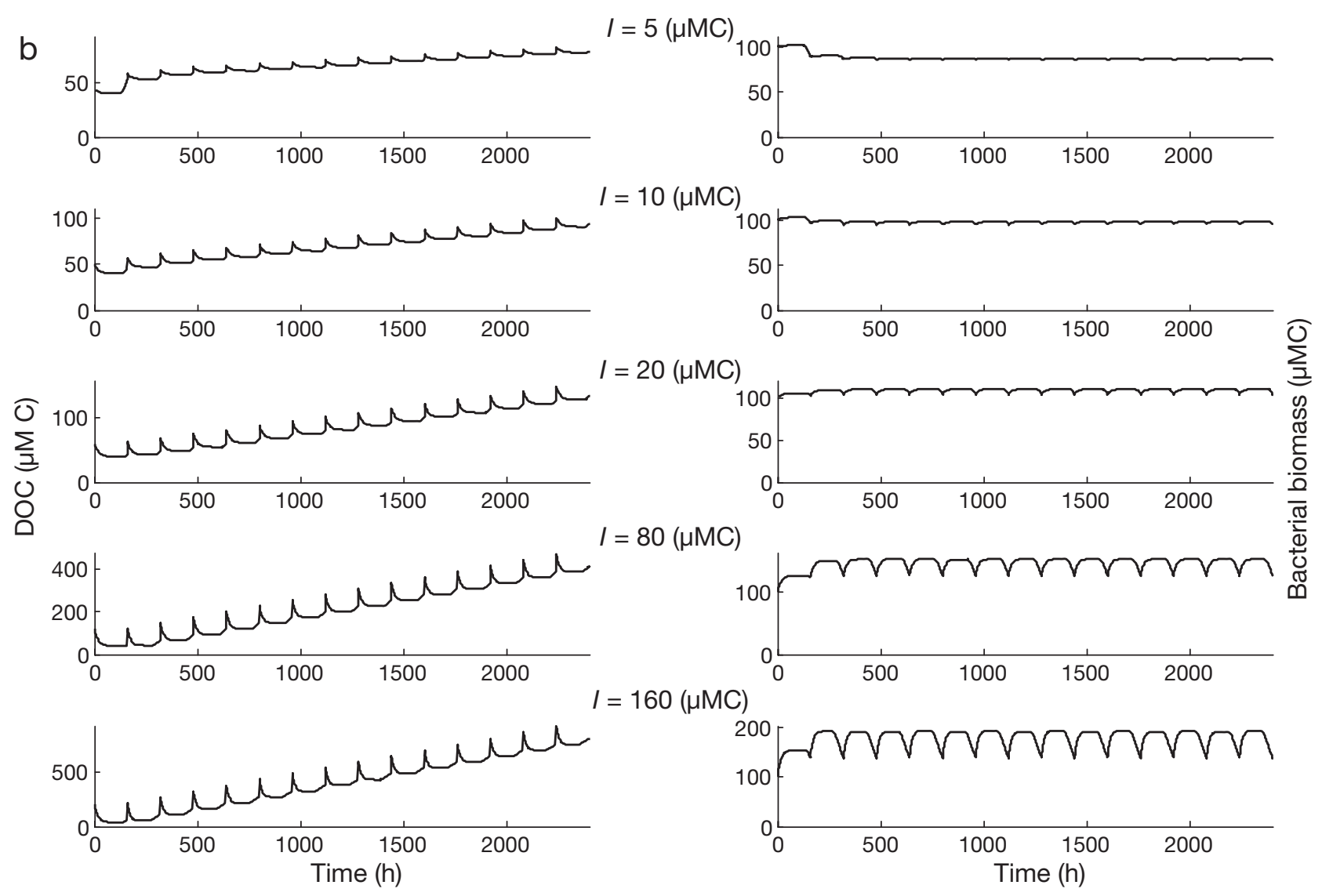

Fig. 5 (continued)

When the pulse period was fixed, the system exhibited more or less the same dynamics with only slight changes between the different L-DOC concentrations tested. With a pulse period of $160 \mathrm{~h}$ (Fig. 5b), the system was almost always at steady-state at the beginning of the simulation. Whatever the concentration of the LDOC pulse, there was a constant increase of total DOC due to the production of R-DOC, and bacterial biomass did not increase. More R-DOC was produced with higher L-DOC pulse concentration. The only difference between simulations was the amplitude of LDOC and bacterial biomass oscillations.

\section{DISCUSSION}

Our results on bacterial DOC production are consistent with previous laboratory studies showing that natural bacterial communities rapidly consume L-DOC and produce DOM that is resistant to decomposition (residence time of 1.2 to $2.3 \mathrm{yr}$ Ogawa et al. 2001). Moreover, those authors stated that the bulk properties of bacterially-derived DOM are similar to those of marine DOM, which is mainly refractory, and confirmed previous results demonstrating that DOC released by bacteria is relatively resistant to degradation (Brophy \& Carlson 1989). Chemical investigations have left most bacterial DOC products molecularly uncharacterised (Ogawa et al. 2001), but more recent studies suggest that this released DOC exhibits a continuum of biological reactivity, ranging from labile to refractory (Gruber et al. 2006, Kaiser \& Benner 2008). Kaiser \& Benner (2008) suggested that about $40 \%$ of this bacterially-derived DOC could be labile or semilabile. Electrospray ionization experiments demonstrated that bacteria in pure culture rapidly take up LDOC and also rapidly produce a complex pool of DOM from a simple labile compound (Gruber et al. 2006). That study also indicated that bacteria may release labile compounds during lag and exponential growth phases, compounds that were incorporated into bacterial biomass or released thereafter as new compounds. This suggests a dynamic cycle of organic compounds utilised by the bacterial strain studied by Gruber et al. (2006). As bacterioplankton represents the largest living surface area in the world's ocean, their release of DOC might account for a substantial fraction (about $25 \%$ ) of the oceanic DOC pool (Kaiser \& Benner 2008). All investigations to date agree that bacterioplankton rapidly take up utilizable DOC and convert it into bio- 
mass, of which a considerable part is released back into the DOC pool. This material could also be an important part of the capsular material (Heissenberger et al. 1996, Stoderegger \& Herndl 1998) that may be utilised by bacterioplankton at a rate 3 orders of magnitude lower than highly labile substrates, such as glucose (Stoderegger \& Herndl 1998). Those results are consistent with our hypothesis of release of refractory material.

Based on observations of DOC and POC dynamics in the present study, we suggest that bacteria release DOC during starvation. In contrast, Gruber et al. (2006) showed that bacteria released organic compounds during all growth phases; however, the nature of the released compounds appeared to differ depending on the growth phase. Specifically, bacteria may release LDOC during lag and growth phases and more refractory compounds during the stationary phase. Unfortunately, we could not detect release of L-DOC in our experiments because it would have been directly assimilated by bacteria. Nevertheless, results of Gruber et al. (2006) are consistent with our observations of refractory material production during the stationary phase. This also agrees with other studies demonstrating that bacterioplankton rapidly release their capsules when they are metabolically inactive (Heissenberger et al. 1996, Stoderegger \& Herndl 1998) and during starvation periods (Wrangstadh et al. 1990). The observations that bacteria are composed of an intracellular pool and capsular material (Stoderegger \& Herndl 1998) are consistent with DEB theory.

The typical DEB growth model for bacteria has been improved by the addition of the R-DOC variable and 2 parameters $\left(j_{M_{V} M}\right.$ and $\left.y_{R M_{V}}\right)$ describing its production by bacteria. We described release of un-utilised DOC by bacteria by accounting for a second maintenance process, which is realised from structure. To our knowledge, this is the first solid experimental support for maintenance in the metabolic organisation of the bacterial cell, where maintenance is paid from reserve under favourable conditions and from structure during starvation. Our model differs from the typical Marr-Pirt model, in which maintenance is always paid from structure and cannot explain DOC production under starvation conditions. The difference only becomes clear in a perturbed system that mimics environmental variability. Some biogeochemical models included bacteria as a source of DOC, mostly due to mortality (Anderson \& Williams 1999), which is clearly different from our observations. Previous modelling studies that included DOC release by bacteria did not mechanistically describe production, and model simulations were not compared to data (Polimene et al. 2006). The 'theoretical' model of Polimene et al. (2006) was incorporated into a coupled biogeochemical-circulation model to explain DOC accumulation observed in coastal areas (Polimene et al. 2007). Although that model reproduced DOC dynamics qualitatively, it underestimated DOC concentrations. Our model simulations, although based on a pure culture experiment, showed that bacteria may indeed contribute to the accumulation of labile DOC in the ambient medium when the input of substrate (L-DOC) is too frequent (Fig. 5a). Conversely, when the substrate additions become less frequent, model simulations showed that bacteria started to release non-labile products, which also accumulated in the ambient water. These 2 contrasting situations could be compared to oceanic systems. Indeed, in eutrophic systems, input of organic matter $(\mathrm{OM})$ is frequent and bacterial biomass could be insufficient to efficiently degrade this incoming substrate, leading to accumulation of labile compounds. In oligotrophic waters, inputs of OM are scarce and bacteria frequently face starvation conditions. Our model would predict this situation to lead to a release of nonlabile products.

Our model could be used as a module for ecosystem modelling. Model simulations with natural DOC concentrations showed that, depending on the environmental situation, both sub-models are not necessarily required. When L-DOC inputs are sufficiently frequent, the growth sub-model would adequately represent bacterial dynamics. In the open ocean where inputs of OM are scarce, or in environments with periodic inputs of L-DOC due to phytoplankton blooms or with variable hydrodynamic conditions, addition of the reduction sub-model becomes necessary. Implementation of our model in a larger model simulating different types of DOC production (phytoplankton release, grazing, freshwater inputs), such as that of Anderson \& Williams (1999), would enable testing of our predictions about when each sub-model is necessary. Moreover, our model is based on mechanistic rules and thus would improve our understanding of DOC dynamics in natural environments.

Our study changes the typical view of carbon cycle modelling, in which bacteria are generally considered to be DOC consumers while contributing DOC only as dead cells. Thus, we need to reconsider some aspects of the carbon cycle at the bacterial level. For instance, we assumed that DOC produced in our bacterial cultures was semi-labile or refractory because it was not consumed. The addition of chemical analyses to our protocol would allow the molecular characterisation of the released compounds. Additional experiments should also determine the lability of this DOC and confirm its bacterial origin. If released DOC cannot be assimilated by other bacterial strains either, it is possible that it may contribute to the accumulation of RDOC in the oceans. Future experiments should also 
use more realistic dynamics of external forcing to highlight key processes of bacterial metabolism, including simultaneous nutrient limitations, to test the more advanced features of DEB-based predictions. Indeed, within the DEB framework, it is conceivable to add state variables for other compounds, such as $\mathrm{N}$ and $\mathrm{P}$, with each having a reserve and a structure component. The influence of nutrient and carbon/energy limitation on each of these compartments and on the release of amount and composition of OM could be tested by including stoichiometric constraints on growth. In order to more closely simulate natural conditions and to obtain a model with a parameterisation applicable to ecosystem modelling, multiple populations, competition and grazing need to be investigated. Finally, addition of a module simulating temperature effects on the different implemented processes would allow a better understanding of the effects of environmental forcing on bacterial growth and DOC cycling, especially in the context of global warming.

Acknowledgements. The authors were supported by a LMGEM research grant by the French National Program for Coastal Environment (AMPLI Project) and by the Foundation TOTAL for the REMECCA program. A Ph.D. scholarship for M.E. came from the French Ministry of Research and Education. We are grateful to M. Garel for his help in the experimental conception and realisation. We thank 3 anonymous reviewers for their comments, which helped to substantially improve the manuscript. We also thank J. Purcell from Sea Pen Scientific Writing LLC for editorial assistance.

\section{LITERATURE CITED}

Anderson TR, Williams PJleB (1998) Modelling the seasonal cycle of dissolved organic carbon at station E-1 in the English Channel. Estuar Coast Shelf Sci 46:93-109

Anderson TR, Williams PJleB (1999) A one-dimensional model of dissolved organic carbon cycling in the water column incorporating combined biological-photochemical decomposition. Global Biogeochem Cycles 13:337-349

Arhonditsis GB, Brett MT (2004) Evaluation of the current state of mechanistic aquatic biogeochemical modeling. Mar Ecol Prog Ser 271:13-26

Azam F (1998) Microbial control of oceanic carbon flux: the plot thickens. Science 280:694-696

Baretta-Bekker JG, Baretta JW, Rasmussen EK (1995) The microbial food web in the European Regional Seas Ecosystem Model. Neth J Sea Res 33:363-379

Baxter M, Sieburth JMN (1984) Metabolic and ultrastructural response to glucose of 2 eurytrophic bacteria isolated from seawater at different enriching concentrations. Appl Environ Microbiol 47:31-38

Blackburn N, Zweifel UL, Hagström ^ (1996) Cycling of marine dissolved organic matter. II. A model analysis. Aquat Microb Ecol 11:79-90

Brandt BW, van Leeuwen IMM, Kooijman SALM (2003) A general model for multiple substrate biodegradation. Application to co-metabolism of structurally nonanalogous compounds. Water Res 37:4843-4854
Brandt BW, Kelpin FDL, van Leeuwen IMM, Kooijman SALM (2004) Modelling microbial adaptation to changing availability of substrates. Water Res 38:1003-1013

> Brophy JE, Carlson DJ (1989) Production of biologically refractory dissolved organic-carbon by natural seawater microbial-populations. Deep-Sea Res I 36:497-507

Carlson CA, Ducklow HW (1995) Dissolved organic carbon in the upper ocean of the central equatorial Pacific Ocean, 1992: daily and finescale vertical variations. Deep-Sea Res II 42:639-656

> Carlson CA, Ducklow HW (1996) Growth of bacterioplankton and consumption of dissolved organic carbon in the Sargasso Sea. Aquat Microb Ecol 10:69-85

> Carlson CA, Giovannoni SJ, Hansell DA, Goldberg SJ and others (2002) Effect of nutrient amendments on bacterioplankton production, community structure, and DOC utilization in the northwestern Sargasso Sea. Aquat Microb Ecol 30:19-36

Cherrier J, Bauer JE (2004) Bacterial utilization of transient plankton-derived dissolved organic carbon and nitrogen inputs in surface ocean waters. Aquat Microb Ecol 35: $229-241$

> Coffin RB, Connolly JP, Harris PS (1993) Availability of dissolved organic carbon to bacterioplankton examined by oxygen utilization. Mar Ecol Prog Ser 101:9-22

Eichinger M, Poggiale JC, Van Wambeke F, Lefèvre D, Sempéré R (2006) Modelling DOC assimilation and bacterial growth efficiency in biodegradation experiments: a case study in the Northeast Atlantic Ocean. Aquat Microb Ecol 43:139-151

Grossart HP, Simon M (2007) Interactions of planktonic algae and bacteria: effects on algal growth and organic matter dynamics. Aquat Microb Ecol 47:163-176

Gruber DF, Simjouw JP, Seitzinger SP, Taghon GL (2006) Dynamics and characterization of refractory dissolved organic matter produced by a pure bacterial culture in an experimental predator-prey system. Appl Environ Microbiol 72:4184-4191

Hanegraaf PPF, Kooi BW, Kooijman SALM (2000) The role of intracellular components in food chain dynamics. CR Acad Sci Paris 323:99-111

Hansell DA, Carlson CA (1998) Deep-ocean gradients in the concentration of dissolved organic carbon. Nature 395: 263-266

> Hansell DA, Bates NR, Gundersen K (1995) Mineralization of dissolved organic carbon in the Sargasso Sea. Mar Chem 51:201-212

> Heissenberger A, Leppard GG, Herndl GJ (1996) Relationship between the intracellular integrity and the morphology of the capsular envelope in attached and free-living marine bacteria. Appl Environ Microbiol 62:4521-4528

Kaiser K, Benner R (2008) Major bacterial contribution to the ocean reservoir of detrital organic carbon and nitrogen. Limnol Oceanogr 53:99-112

Kalscheuer R, Stoveken T, Malkus U, Reichelt R and others (2007) Analysis of storage lipid accumulation in Alcanivorax borkumensis: evidence for alternative triacylglycerol biosynthesis routes in bacteria. J Bacteriol 189:918-928

> Kooi BW, Kooijman SALM (1994) The transient behaviour of food chains in chemostats. J Theor Biol 170:87-94

Kooijman SALM (2000) Dynamic energy and mass budgets in biological systems, 2nd edn. Cambridge University Press, Cambridge

Kooijman SALM, Kooi BW, Hallam TG (1999) The application of mass and energy conservation laws in physiologically structured population models of heterotrophic organisms. J Theor Biol 197:371-392 
Lagarias JC, Reeds JA, Wright MH, Wright PE (1998) Convergence properties of the Nelder-Mead simplex method in low dimensions. SIAM J Optim 9:112-147

Lancelot C, Staneva J, Van Eeckhout D, Beckers JM, Stanev E (2002) Modelling the Danube-influenced north-western continental shelf of the Black Sea. II. Ecosystem response to changes in nutrient delivery by the Danube River after its damming in 1972. Estuar Coast Shelf Sci 54:473-499

- Martinussen I, Thingstad TF (1987) Utilization of N, P and organic-C by heterotrophic bacteria. II. Comparison of experiments and a mathematical model. Mar Ecol Prog Ser 37:285-293

McManus GB, Peterson WT (1988) Bacterioplankton production in the nearshore zone during upwelling off central Chile. Mar Ecol Prog Ser 43:11-17

Michaelis L, Menten ML (1913) Die Kinetik der Invertinwirkung. Biochem Z 49:334-336

Miki T, Yamamura N (2005) Effects of asynchronous fluctuations in DOC supply and bacterial growth on biodegradation efficiency. Ecol Modell 183:281-299

Monod J (1942) Recherches sur la croissance des cultures bactériennes. Ph.D. Thesis, University of Paris (in French)

Mouriño-Carballido B, Neuer S (2008) Regional differences in the role of eddy pumping in the North Atlantic Subtropical Gyre: historical conundrums revisited. Oceanography 21:52-61

Ogawa H, Amagai Y, Koike I, Kaiser K, Benner R (2001) Production of refractory dissolved organic matter by bacteria. Science 292:917-920

Polimene L, Allen JI, Zavatarelli M (2006) Model of interactions between dissolved organic carbon and bacteria in marine systems. Aquat Microb Ecol 43:127-138

Polimene L, Pinardi N, Zavatarelli M, Allen JI, Giani M, Vichi M (2007) A numerical simulation study of dissolved organic carbon accumulation in the northern Adriatic Sea. J Geophys Res 112, C03S20, doi:10.1029/2006JC003529

Raguénès GHC, Peres A, Ruimy R, Pignet P and others (1997) Alteromonas infernus sp. nov., a new polysaccharide-producing bacterium isolated from a deep-sea hydrothermal vent. J Appl Microbiol 82:422-430
Raick C, Delhez EJM, Soetaert K, Gregoire M (2005) Study of the seasonal cycle of the biogeochemical processes in the Ligurian Sea using a 1D interdisciplinary model. J Mar Syst 55:177-203

Robinson JP, Grégori G (2007) Principles of flow cytometry. In: Dolezel J, Greilhuber J, Suda J (eds) Flow cytometry with plant cells. Wiley-VCH, Weinheim, p 19-40

Sempéré R, Yoro SC, Van Wambeke F, Charrière B (2000) Microbial decomposition of large organic particles in the northwestern Mediterranean Sea: an experimental approach. Mar Ecol Prog Ser 198:61-72

Sempéré R, Dafner E, Van Wambeke F, Lefèvre D and others (2003) Distribution and cycling of total organic carbon across the Almeria-Oran Front in the Mediterranean Sea: implications for carbon cycling in the western basin. J Geophys Res 108(C11), 3361, doi:10.1029/2002JC001475

Stoderegger K, Herndl GJ (1998) Production and release of bacterial capsular material and its subsequent utilization by marine bacterioplankton. Limnol Oceanogr 43: 877-884

Tolla C, Kooijman SALM, Poggiale JC (2007) A kinetic inhibition mechanism for maintenance. J Theor Biol 244: 576-587

Van Wambeke F, Lefèvre D, Prieur L, Sempéré R, Bianchi M, Oubelkheir K, Bruyant F (2004) Distribution of microbial biomass, production, respiration, dissolved organic carbon and factors controlling bacterial production across a geostrophic front (Almeria-Oran, SW Mediterranean Sea). Mar Ecol Prog Ser 269:1-15

Williams PJleB (2000) Heterotrophic bacteria and the dynamics of dissolved organic material. In: Kirchman DL (ed) Microbial ecology of the oceans. Wiley-Liss, New York, p 153-199

> Wrangstadh M, Szewzyk U, Ostling J, Kjelleberg S (1990) Starvation-specific formation of a peripheral exopolysaccharide by a marine pseudomonas sp, Strain-S9. Appl Environ Microbiol 56:2065-2072

> Zweifel UL, Norrman B, Hagström Å (1993) Consumption of dissolved organic carbon by marine bacteria and demand for inorganic nutrients. Mar Ecol Prog Ser 101:23-32 
Appendix 1. Detailed description of the model construction and calibration

\section{Construction of the DEB model}

In the following section, we specify the mass fluxes (Fig. 1) $j_{\cdot{ }_{1} \cdot 2}$ and $j *_{1}^{2}$ represent the specific fluxes of compound (state variable) $\cdot \cdot_{1}$ associated with the process $\cdot{ }_{2}$, while the absolute fluxes are $\dot{J}_{*_{1}{ }_{2}}=j \cdot{ }_{1}{ }_{2} M_{V}$ (Kooijman 2000); the notation $j \cdot{ }_{1}^{2}$ here is used specifically for maintenance fluxes. The various processes involved, specified by $\cdot 2$, are: assimilation (A), maintenance $(\mathrm{M})$, and growth $(\mathrm{G})$. The various compounds involved, specified by $\cdot 1$, are the state variables: L-DOC labile dissolved organic carbon $(L)$, reserve $\left(M_{E}\right)$, structure $\left(M_{V}\right)$ and R-DOC refractory dissolved organic carbon $(R) \cdot y \cdot 1 \cdot 2$ represents the efficiency of transformation of compound ${ }^{*} 2$ to compound ${ }^{*} 1$ (Table 1 ).

Table A1 provides the foundation for the differential equations of the 4 state variables by multiplying the column of the considered state variable $\left(L, R, M_{E}\right.$ and $\left.M_{V}\right)$ by the column of the specific rates and by the structural biomass $M_{V}$ :

Where $j \cdot$, the specific fluxes, are defined in Table A1:

$$
\begin{aligned}
& \frac{\mathrm{d} L}{\mathrm{~d} t}=j_{L} M_{V} \\
& \frac{\mathrm{d} M_{E}}{\mathrm{~d} t}=j_{M_{E}} M_{V} \\
& \frac{\mathrm{d} M_{V}}{\mathrm{~d} t}=j_{M_{V}} M_{V} \\
& \frac{\mathrm{d} R}{\mathrm{~d} t}=j_{R} M_{V}
\end{aligned}
$$

$$
\begin{aligned}
& j_{L}=-j_{M_{E} A_{c}}-j_{M_{E} A_{\mathrm{a}}}=-y_{L M_{E}} j_{M_{E} A} \\
& j_{M_{E}}=j_{M_{E} A_{\mathrm{a}}}-j_{M_{E}}^{M}-j_{M_{E} G_{\mathrm{c}}}-j_{M_{E} G_{\mathrm{a}}}=j_{M_{E} A}-j_{M_{E}}^{M}-j_{M_{E} G} \\
& j_{M_{V}}=-j_{M_{V}}^{M}+j_{M_{E} G_{\mathrm{a}}}=y_{M_{V} M_{E}} j_{M_{E} G}-j_{M_{V}}^{M} \\
& j_{R}=y_{R M_{V}} j_{M_{V}}^{M}
\end{aligned}
$$

Maintenance always has priority over growth and has to be paid to maintain the integrity of the cell. The (total) specific cost for maintenance $\left(j_{M_{E} M}\right)$ is constant, but maintenance is paid from mobilised reserve if the flux is large enough ( $\left.j_{M_{E}}^{M}\right)$ (Fig. 1a), but otherwise structure itself is used to pay the remaining part of the maintenance $\operatorname{costs}\left(j_{M_{V}}^{M}\right)$, which causes shrinking of the cell and R-DOC production (Fig. 1b). We used a switch formulation to specify the use of one or the other type of maintenance (Tolla et al. 2007). If the amount of reserve is sufficient to ensure all the maintenance, thus $j_{M_{E}}^{M}=j_{M_{E} M}$. This is the case when $j_{M_{E} C}>j_{M_{E} M}$, where $j_{M_{E} C}$ is the catabolic flux from reserve, i.e. the reserve loss flux, and can be calculated from:

$$
\begin{aligned}
& \frac{\mathrm{d} m_{E}}{\mathrm{~d} t}=j_{M_{E} A}-k_{E} m_{E} \quad(\text { Kooijman, 2000) } \\
& \frac{\mathrm{d} M_{E}}{\mathrm{~d} t}=M_{V} \frac{\mathrm{d} m_{E}}{\mathrm{~d} t}+m_{E} \frac{\mathrm{d} M_{V}}{\mathrm{~d} t}=M_{V}\left(j_{M_{E} A}-k_{E} m_{E}\right)+\dot{r} M_{E}
\end{aligned}
$$

where $\dot{r}=\frac{\mathrm{d} M_{V}}{\mathrm{~d} t} / M_{V}$ is the specific growth rate and $m_{E}=\frac{M_{E}}{M_{V}}$ (Table 1)

$$
j_{M_{E}}=\frac{\mathrm{d} M_{E} / \mathrm{d} t}{M_{V}}=j_{M_{E} A}-m_{E}\left(k_{E}-\dot{r}\right)=j_{M_{E} A}-j_{M_{E} C}
$$

Thus, $j_{M_{E} C}=m_{E}\left(k_{E}-\dot{r}\right)$, and when $m_{E}\left(k_{E}-\dot{r}\right)>j_{M_{E} M}, j_{M_{E}}^{M}=j_{M_{E} M}$ and, consequently, $j_{M_{V}}^{M}=0$. Otherwise, when

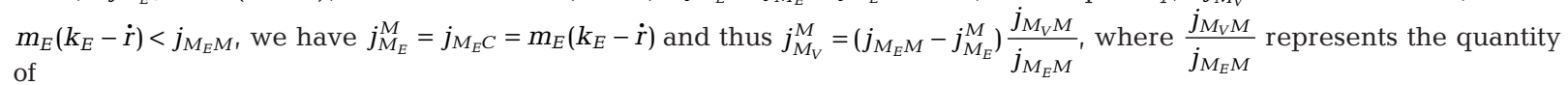
energy spent to transform compounds from reserve to structure and then from structure to maintenance, which is obviously more costly than the direct transformation from reserve to maintenance. If maintenance is fully paid from reserve, the remaining energy can be spent for growth which amounts to $j_{M_{E} G}=y_{M_{E} M_{V}} \dot{r}$ (Kooijman 2000), and if maintenance is also provided from structure, growth of the structure is no longer possible and $j_{M_{E} G}=0$. We can thus write:

$$
\begin{aligned}
& j_{M_{E}}^{M}=\min \left(j_{M_{E} M}, m_{E}\left(k_{E}-\dot{r}\right)\right) \\
& j_{M_{V}}^{M}=\max \left(0, j_{M_{E} M}-j_{M_{E}}^{M}\right) \frac{j_{M_{V} M}}{j_{M_{E} M}} \\
& j_{M_{E} G}=\max \left(0, \dot{r} y_{M_{E} M_{V}}\right)
\end{aligned}
$$

The model thus respects the condition of a constant maintenance rate: 


$$
j_{M_{E} M}=\frac{j_{M_{E}}^{M}}{1-j_{M_{V}}^{M} / j_{M_{V} M}}
$$

We now have to specify the specific growth rate $\dot{r}$ :

$$
\begin{array}{ll}
\text { if } m_{E}\left(k_{E}-\dot{r}\right)>j_{M_{E} M} & \text { if } m_{E}\left(k_{E}-\dot{r}\right)<j_{M_{E} M} \\
\dot{r}=\frac{k_{E} m_{E}-j_{M_{E} M}}{m_{E}+y_{M_{E} M_{V}}} & \dot{r}=\frac{k_{E} m_{E}-j_{M_{E} M}}{m_{E}+j_{M_{E} M} / j_{M_{V} M}}
\end{array}
$$

It should be also noted that $m_{E}\left(k_{E}-\dot{r}\right)>j_{M_{E} M} \Rightarrow m_{E} k_{E}>j_{M_{E} M}$.

For a single substrate, the assimilation flux is (Kooijman 2000):

$$
j_{M_{E} A}=j_{L A m} y_{M_{E} L} \frac{L}{K+L}
$$

Finally, we can write the complete model:

$$
\left\{\begin{array}{l}
\frac{\mathrm{d} L}{\mathrm{~d} t}=j_{L} M_{V}=-y_{L M_{E}} j_{M_{E} A} M_{V}=-j_{L A m} \frac{L}{K+L} M_{V} \\
\frac{\mathrm{d} M_{E}}{\mathrm{~d} t}=j_{M_{E}} M_{V}=\left(j_{L A m} Y_{M_{E} L} \frac{L}{K+L}-\min \left(j_{M_{E} M}, m_{E}\left(k_{E}-\dot{r}\right)\right)-\max \left(0, \dot{r} y_{M_{E} M_{V}}\right)\right) M_{V} \\
\frac{\mathrm{d} M_{V}}{\mathrm{~d} t}=j_{M_{V}} M_{V}=\left(y_{M_{V} M_{E}} \max \left(0, \dot{r} y_{M_{E} M_{V}}\right)-\max \left(0, j_{M_{E} M}-j_{M_{E}}^{M}\right) \frac{j_{M_{V} M}}{j_{M_{E} M}}\right) M_{V} \\
\frac{\mathrm{d} R}{\mathrm{~d} t}=j_{R} M_{V}=y_{R M_{V}} \max \left(0, j_{M_{E} M}-j_{M_{E}}^{M}\right) \frac{j_{M_{V} M}}{j_{M_{E} M}} M_{V}
\end{array}\right.
$$

This model can also be written as follows:

$$
\begin{aligned}
& \frac{\mathrm{d} L}{\mathrm{~d} t}=-j_{L A m} \frac{L}{K+L} M_{V} \\
& \text { if } k_{E} M_{E}>j_{M_{E} M} M_{V} \quad \text { if } k_{E} M_{E}<j_{M_{E} M} M_{V}
\end{aligned}
$$

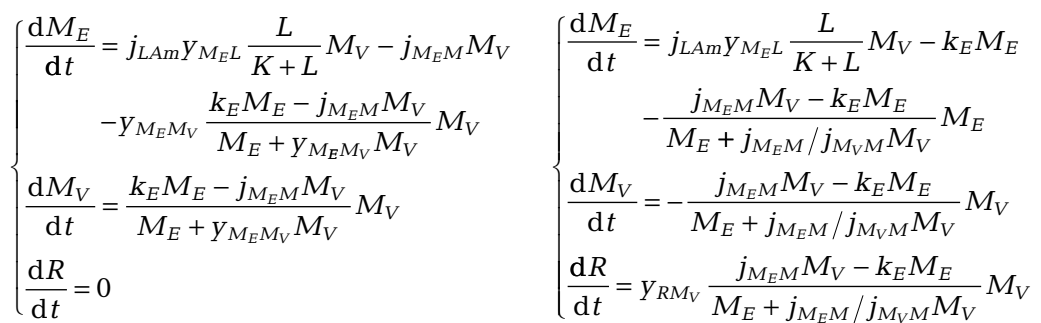

\section{Calibration}

The calibration routine provided a value for the half-saturation constant $K$ significantly higher than $L$ values $(K>>L)$. We thus eliminated the maximum uptake rate $\left(j_{L A m}\right)$ and the half-saturation constant $K$ and used a linear equation for uptake with a new parameter: $\alpha=\frac{j_{L A m}}{K}$ and $\frac{\mathrm{d} L}{\mathrm{~d} t}=-\alpha L M_{V}$. Consequently, we used this new uptake formulation with the estimated $\cdot$ value in the rest of the manuscript. This reduced the model to 7 parameters and 4 state variables.

Table A1. The model was developed based on the mass conservation law and this table, by multiplying the column of the considered state variable $\left(\mathrm{L}, \mathrm{R}, M_{E}\right.$, and $M_{V}$ ) by the column of the specific rates and by the structural biomass $M_{V}$. $L$ : labile dissolved organic carbon (DOC) or L-DOC $R$ : refractory DOC or R-DOC; $M_{V}$ : structure concentration; $M_{E}$ : reserve concentration

\begin{tabular}{llccccc}
\hline Symbol & Processes & L: L-DOC & R: R-DOC & $M_{E}$ : reserve & $M_{V}$ : structure & specific rates \\
\hline$A_{\mathrm{c}}$ & Assimilation (catabolic) & -1 & 0 & 0 & 0 & $j_{M_{E} A_{c}}=\left(y_{L M_{E}}-1\right) j_{M_{E} A}$ \\
$A_{\mathrm{a}}$ & Assimilation (anabolic) & -1 & 0 & 1 & 0 & $j_{M_{E} A_{\mathrm{a}}}=j_{M_{E} A}$ \\
$M_{E}$ & E-maintenance & 0 & 0 & -1 & 0 & $j_{M_{E}}^{M}$ \\
$M_{V}$ & V-maintenance & 0 & $y_{R M_{V}}$ & 0 & -1 & $j_{M_{V}}^{M}$ \\
$G_{\mathrm{C}}$ & Growth (catabolic) & 0 & 0 & -1 & 0 & $j_{M_{E} G_{\mathrm{c}}}=\left(1-y_{M_{V} M_{E}}\right) j_{M_{E} G}$ \\
$G_{\mathrm{a}}$ & Growth (anabolic) & 0 & 0 & -1 & 1 & $j_{M_{E} G_{\mathrm{a}}}=y_{M_{V} M_{E}} j_{M_{E} G}$ \\
\hline
\end{tabular}

